\title{
SCALE ON PAPER BETWEEN \\ TECHNIQUE AND IMAGINATION. \\ EXAMPLE OF CONSTANT'S DRAWING HYPOTHESIS
}

\author{
A B S T R A C T
}

The procedure of scaling is one of the elemental routines in architectural drawing. Along with paper as a fundamental drawing material, scale is the architectural convention that follows the emergence of drawing in architecture from the Renaissance. This analysis is questioning the scaling procedure through the position of drawing in the conception process. Current theoretical researches on architectural drawing are underlining the paradigm change that occurred as a sudden switch from handmade to computer generated drawing. This change consequently influenced notions of drawing materiality, relations to scale and geometry. Developing the argument of scaling as a dual action, technical and imaginative, Constant's New Babylon drawing work is taken as an example to problematize the architect-project-object relational chain. 


\section{INTRODUCTION}

This study intends to question the practice of scaling in architectural drawing as one of the elemental routines in the contemporary work of an architect. The problematization is built on the relation between an architect and the drawing process while examining the evolving role of drawing in the architectural profession. Scale is here taken as a multivalent procedure pegged on two main anchors: as a conception tool applied to the drawing process and as a communication competency required as a part of the drawing apparatus. When analysing scale, the materiality of drawing emerged as an essential phenomenon and is consequently treated in this analysis as a parallel research layer. The interrogation on scale related to the drawing's materiality is particularly adequate in current moment where the medium of architectural drawing is being reevaluated and rethought.

Scaling in architecture is inseparably linked to the emergence of the architectural drawing. This work examines the dynamics between architecture profession and paper drawing from its beginnings to nowadays. The argument is relying on studies and analyses of contemporary architects and architecture theoreticians who were dealing with referent problems. Primarily, this interrogation is focusing on the developement of drawing as a dominant architecture media and how the practice of scaling followed its evolving complexity and sophistication (Emmons, Evans, Frascari, Sheer). The scale drawing is consequently being analysed through its organic relationships with paper (Frascari, Wigley) and geometry (Emmons). Finally, using the notion of proportional relations, scale drawing is being questioned through its polarity between imagination and technique (Emmons, Evans) and problematized with the example of Constant's drawing practice (Wigley).

The example of Constant's drawing is based on Mark Wigley's studies on the phenomenon of drawing. According to Wigley, Constant had a very specific relation with the drawing medium, which held a peculiar place in the production and development of the idea of New Babylon. As a utopian project designed over almost two decades (1956-74), New Babylon changed and transformed with time following Constant's activist engagement within the Situationist International group and his resignation from it. The very essence of this project was criticism of society constellations using the means of architecture. Unfolding the hypothesis of active living as a dominant preoccupation of New Babylon inhabitants, Constant was rethinking all scales of society through space: from individual and personal relations to living space, through privatepublic space of neighbourhoods to a universal system of spaces applied on a 
planetary level. Arguing over various media materialities that Constant used in his work and also the fact that New Babylon was never realized as a built object, Wigley claims that "Constant was in every sense a paper architect."

\section{CRAFT ING, IMAG INING, COMMUNICAT ING}

The reflection on drawing in architectural profession has been occupying numerous architects and architecture theoreticians during the past decade. The main reason can be captured in the paradigm shift that occurred as a precipitous switch from hand drawing to computer generated drawing. With the current undeniable dominance of computer drawing, it is a time distance (of two decades or so) that enables a possible analysis on the transformation that followed this major shift. In his 2014 book The death of drawing: architecture in the age of simulation, David Sheer aims to review and clarify the contemporary role of architectural drawing in the age of digitalisation. Relying on his personal experience as an architect passionately involved with hand drawing, he is analysing the main transition to computer added design (CAD) and other computer software applications able to produce drawings as well as three dimensional models.

Sheer is considering that the role of architectural drawing within the modern profession is largely influenced by circumstances in the Renaissance when the architect was separated from the building site. He is pointing out Alberti's observation that the architect's superior role is to design, not to built, considering his approach as an intellectual authorship, above the builder's engagement on "how" something is built. Sheer argues that this is when "drawing became essential to architecture as the expression of architectural ideas, the architect's work product and the link between thought, design and construction." According to him, architectural drawing developed its duality in "two essential aspects: as a medium and as a craft." This dual character of the drawing enables it to structure and materialize the author's idea, and at the same time to communicate this idea further, to the building site. This duality can also serve as an analytical platform for the multiple aspects and positions drawing held in the architectural process throughout history and that were enabled by the wide use of paper during the Renaissance period. The practice of paper drawing that consequently distanced the architect from the site implied the practice of scaling as a procedure for crafting and communicating the idea and measurements. Besides its communication purpose for the architect absent from the site, scaling on paper became needed as the author's imaginary world and auto-critique tool. 
From the very beginning of paper drawing, the relationship between drawing and architecture as a profession has been dynamic and diverse. Through its development, drawing has invented and improved its own codifications and systems of rules - like particular views, units of measurement, scaling, etc. As it proceeds from it's main polarity - as a medium and as a craft - drawing codes and roles vary depending on the position of drawing in the architectural process. Robin Evans is problematising this multiple position of drawing by focusing on the complexity of the drawing-building relation. He considers that "recognition of the drawing's power as a medium turns out, unexpectedly, to be recognition of the drawing's distinctness from and unlikeness to the thing that is represented, rather than its likeness to it which is neither as paradoxical nor dissociative as it may seem." Speaking about drawing as a medium, Evans discusses drawing as a distinctive communication tool and architecture as a language. Even if he notices the impulse in architectural and cultural theory to create analogies between architecture and language, he claims that in fact "a great deal in architecture may be language-like without being a language. ${ }^{\prime 4} \mathrm{He}$ thinks that language as a category can outspeak architecture and at the same time simplify the visuality of architecture. And he assumes that this theoretical thesis of architecture as language would be possible to work if it wasn't for the architectural drawing which "for architecture, even in the solitude of pretended autonomy, [is] one unfailing communicant..." So, the convoluted position that architectural drawing has in the architectural profession and its polyvalent relation to building lies in its edge and challenge of the main transmitter: between the architect and his/her idea, between the architect and the builder, but also as an analysis and critique medium.

\section{PAPER(LESS) ARCHITECTURE}

Once it had distinguished an architect from a builder and a drawing from a building site, paper as a material continued to influence the chain of relations architect-project-object. The drawing nature of the communicant also coincided with the fact of its materiality and objecthood. The development in the paper's technical performances through history was accompanied by the invention and the reinvention of drawings techniques, tracing instruments and drawing conventions. In his essay "A reflection on paper and its virtues within the material and invisible factures of architecture" Marco Frascari argues about the essential role of paper as a material throughout the whole architectural conception process. He points out how changes of this material and its development influenced the architect's work and all related procedures. ${ }^{6}$ Although architecture as a discipline has always maintained tight connections 
with technology development, is inspired and tends to follow newest technology challenges, its accordance with paper exceeds other technology fascinations. Distinguishing active technology from passive, Frascari considers that presently in the profession architects are employing paper simply as a passive instrument, as a support of finished drawing. He assumes that this is the case because "they do not realize that during the drafting procedure, subtile manipulations and changes in the paper play an influential continuocounterpoint, essential for the play of an architect's imagination." material properties of paper, its qualities and performances, as well as the materiality of traced lines are both hugely influential to the architectural design process and to the possible decisions about the conceived space.

In this study on architecture-paper relations, Frascari examines the genealogy of the drawing materiality. He explains that before the fourteenth century's crossroad of their separate development, paper was used from mid-eighteenth century primarily for calligraphy works while architecture was produced exclusively directly on site. This reflection indicates that the very beginning of drawing is not related to paper but to the building site. Frascari weighs on this to tackle the inaccurate title of our current profession as "paperless architecture", when paradoxically paper is used more than ever attesting the huge quantities ending in the paper bin. ${ }^{8}$ So, the current fallacy in architectural production is that the drawing-paper relation is considered as "an automatic transcription onto a surface of ideas that are already clear in architect's mind." Even if the working hand drawing is existing in the process, it is mostly perceived just as a necessary inter-step in digital drawing production and ending up in the wastepaper bin. For Frascari, the importance of the drawing, its material existence on the paper with line traces, expand far beyond the widespread "digital imperative" in today's architecture. Insisting on the materiality of paper and on the drawing as an autonomous object, he states that "drawings are not the simulacra of works of architecture to be built, restored or modified but they are works of architecture in themselves." 10

Wigley correspondingly argues in his research on New Babylon drawings that paper is generally taken just as a material that supports the medium of drawing. Like Frascari, he considers that the materiality of paper is critical for the drawer and the drawing technique. Paper's material characteristics like colour, thickness, weight, texture, opacity in interaction with ink are resulting a wide spectre of drawing performances. Rethinking the objecthood of drawing, Wigley is taking exhibition gallery conditions as an obvious and extreme example of drawing's treatment being displayed in a frame. He says that paper is here taken as a neutral surface, "as if it is not really there, as if it occupies a 
liminal space between material and immaterial. This allows it to act as a bridge across the classical divide between material and idea. Drawings are seen as a unique form of access to the thoughts of the people that make them." ${ }^{11}$ This could thus implicate that questions on paper materiality are contributing to the drawing's appearance as a document and autonomous work of architecture between technique and imagination.

\section{NEED FOR SCALE}

In the recently published book Technical drawing, Bert Bielefeld and Isabela Skiba propose a definition of scale: "A scale describes the relationship between the dimensions of an element in a drawing and in the original size." 12 The authors differentiate three principal scale types: "original scale (scale 1:1) as the natural scale; enlarged scale (scale $\mathrm{x}: 1$ ), in which one element is drawn larger than its natural size by a certain multiple; reduced scale, (scale 1:x), in which one element is reproduced smaller than its actual size by a certain multiple." 13 The further explanation shows that reduced scales are used for construction drawings and that reduction falls with precision and detail in the design process. The authors equate technical and construction drawing in order to precisely define drawing rules and conventions throughout multiple standards. They are defining drawing procedures by striving for generalization and uniformization as means of communication, yet Bielefeld states that "there is no one correct way of preparing and creating a design or working drawing. Construction drawings are always an act of self-expression by the person preparing them; they have a personal touch." ${ }^{14}$ Consequently, there is no drawing that is purely technical nor purely imaginative and self-expressive. If these two categories of drawing are defining the opposite sides of a spectrum, the praxis of drawing is always on nuances in-between.

In his research on scale, Paul Emmons does not make similar distinction between different kinds of drawing nor different stages in the drawing process, working with scale is rather tightly connected with building on site. He finds that it is specifically this lively dynamic relation between the architect and the building process that is essential for an empathetic approach to scaled drawing and claims that "...scale is not merely a technical issue, but a question of the nature of architectural conception." ${ }^{15}$ His research shows that scale was used "for at least several thousands years" assuming that both ancient Egyptians and Greeks had scale rules. As we referred in a previous analysis on drawing development, he considers that the concept of modern architecture scale drawing started with the Renaissance due to the wider availability and usage of paper and the detachment of the architect from the construction site. ${ }^{16}$ 
The use of scale during the Renaissance started without conventions, every author tried to find his own way of performing a scale procedure. Measures were strictly related to the human body, where the finger, the palm and the foot were frequently used. These measures were varying depending on the geographical region or on the material used to measure. Emmons points out Sebastiano Serlio and Andrea Palladio who provided on their drawings a full-size dimension of the basic measures, but the relation between these measures and the rest of the drawing varied and changed through time. Before the conventional scale line on a drawing paper was adopted as a standard, a whole process of rethinking the precise and most convenient way of communicating drawing to the builders on a site preceded. The imperative was to find the appropriate translation from the drawing to the building. Reviewing Renaissance treaties and their contemporary interpretations, Emmons explains the concept of scale line: "Since early architectural drawings were made to represent procedures on the construction site, the scale representations derived from the knotted lines of ropes or chains that were stretched on site to lay out the building in full size. The procedure was to begin by stretching a rope along the major axis and then subsidiary measurements were pulled from the centreline. The graphic scale line is drawn out on paper just as the rope lines were stretched on site." ${ }^{\prime 17}$ When in the nineteenth century the scale line was traced on paper and became part of the drawing, scale was for Emmons reduced to a "solely mental act of measurement" that lost its embodied relation. Instead, he points out the value of contextualized scale relations applied during the sixteenth century as barshaped scales on flat plates of different materials with multiple engraved scales from various localities. He explains that these were considered as drawing tools and used together with compasses.

Evans is discussing two different positions of drawing due to their relation with the body, "one is emphasizing the corporeal properties of things made, the other concentrating on the disembodied properties in the drawing." Even if these two are the opposite, they are compatible: "in the one corner, involvement, sustainability, tangibility, presence, immediacy, direct action; in the other, disengagement, obliqueness, abstraction, mediation and action at distance. ${ }^{18}$ This ambivalence of architectural drawing he attributes it to the fact that essential specificity of architecture is whether or not drawing is considered as its final outcome. Thus, drawing stays in this uncomfortable place, between these two opposites forms of which neither is absolutely correct. Comparing drawing to language, Evans argues that translation is a complex and conditional process, meaning that it is misleading to understand drawing as directly related 
to the building and as an instruction for the building. But at the same time he underlines that taking the architectural drawing as an art object completely detached from the building is its overvaluing. ${ }^{19}$

SCALING AS IMAGINATION, GEOMETRY AS IMAGINATION CONTROL

The transition from tactile hand drawing and its polemical objecthood to complete relativisation of its materiality in computer production transformed the relational chain architect-project-object and consequently the matter of scale. It is probable that the essential role in this major shift is in a ligament between scale and geometry. Emmons assumes that scale is absent in contemporary architecture drawing where drawing is produced on computer using CAD software. ${ }^{20}$ Drawing in CAD is produced at a full 1:1 scale, accommodating an illusion around the drawing process, but the fact is that the drawer is constantly using the zoom in and zoom out commands, enlarging and minimizing the drawn material, thus persistently changing his perceptive relation with the drawn space. The only moment where scaling occurs with $\mathrm{CAD}$ drawing is when preparing its printing on paper. Scale is then reduced to pure information at the end of the design process, as a passive representational consensus. As Emmons notices, this odd relation to scale in CAD drawing is bizarrely appearing when scaling the text box to fit the appropriate size for printing. ${ }^{21}$ In their technical drawing explanation, Bielefeld and Skiba argue that CAD software simplifies scale relations using 1:1 drawing and that CAD "drawing is additionally provided with an output or reference scale, which defines the scale on which the drawing will be printed and output later. Pen and lettering also adapt this reference scale..." ${ }^{22}$ It is not a question whether scale has been reduced to a representational procedure detached from drawing techniques, from its materiality, as well as from the relation with the architect's gesture. For Emmons, CAD is a "myth of exactness of full scale drawing" and the main problem in CAD's dominance over the scaled drawing is that "man the measure is replaced with man the measurer." He states that scale is a crucial imagination tool when conceiving space in an architectural drawing. Imagination in this light includes that the architect's "empathetic bodily projection is (as) critical to imagining a future edifice." ${ }^{23}$

Another important concern relating CAD logic for Emmons is its foundation on the purely numerical fundamentals of Cartesian geometry. He attributes this objectivization of geometry to rationalist French philosopher Nicolas Malebranche (1638-1715) and his interpretation of Descartes' philosophy. 
According to Malebranche, human perception of the material world is subjective and as such is not reliable to neither work nor study with. He suggests that "geometry, then, should be regarded as a kind of universal science that opens the mind, makes it attentive, and gives it the skill to control the imagination and to draw from it all help it can give; for with the help of geometry the mind controls the imagination, and a controlled imagination sustains the mind's perception and attention." 24

For Scheer, this "imagination control" in geometry conducted drawing started as early as the third century BC, with Euclidean space and Euclid's axioms. Relying on Kant's idea of "mental drawing", Scheer is discussing drawing as an intermedia between the invisible (idea, ideal) and the visible form. In this sense, Sheer thinks that analog drawing is essential but needs to be redone every time the idea contained in the mental image changes. This because once the drawing is made, the process of creation is reduced to one geometry. In his further elaboration and through comparative analysis, Sheer thinks that even if Cartesian geometry is developed from Eudlid's ideas, its "descriptive framework" enlarges geometrical possibilities for architectural space. ${ }^{25}$

Opposing Malebranche's theory of the "disembodied scientific eye", Emmons is calling on literature from that period which was just as Malebranche's work influenced by the inventions and use of the microscope and the telescope during the seventeenth and eighteenth centuries. Emmons focuses on two works: Jonathan Swift's Gulliver's travels (1726) and Voltaire's Micromégas (1738-1752). Both these novels were celebrating a fascination for scale and proportion: Gulliver related to scale in both directions - gargantuan and tiny - while in Voltaire's story, proportions play between the sizes of a planet and an inhabitant. As Emmons says: "Both of these stories project other possible worlds through bodily presence"26, they use scaling as a "perception technique", an instrument for observing and analysing the environment. In the context of drawing and architectural conception, this "perception technique" would mean that scaling is a dynamic function that feeds back conceptual decisions to the drawer. ${ }^{27}$

Emmons concludes that "the making of architectural drawings must engage the entire body into the physical act of imagination to understand scale." He claims that a specific kind of imagination is required for the drawing process: the imaginative inhabitation of drawing. For this imagination scaling is a way for the architect to inhabit his/hers drawing, to walk through drawn spaces. ${ }^{28}$ 


\section{SCALE AND PROPORTION: WHO LIVES IN DRAWINGS?}

The alienation of an architect from his conceptual approach under the veil of mathematical objectification of applied geometry was an issue that also occupied Le Corbusier's research practice. The focus of his critique was that the meter - established in the eighteenth century as a basis for an international unit of measurement - was not related in any way to the human body that inhabits the designed space. He claims that architecture has to be a matter of embodiment and for this purpose invented the Modulor, a measurement system embodying the ultimate inhabitant of architectural drawings. ${ }^{29}$

The uniqueness of Modulor's juxtaposing objectivisation-technique and embodiment-imagination exists in the harmonious consensus of human body notions and mathematical approach. It contains two measurement systems, both linked with the golden ratio: the red - developed with Fibonacci sequence, and the blue - numerical, contains one unit, a double unit and three golden ratios. Le Corbusier believed the golden ratio to be a proportional model that kept proportions with the human body and nature. The first version of the Modulor was dimensioned according to an average measurement of a Frenchmen 175 $\mathrm{cm}$ tall, but the intent for international usage implied translation to the system of inches. Thus, after rethinking admeasurement and adjusting the Modulor, drawings were inhabited by taller Englishman-like bodies. The figure of a man with his hand raised in the second and final version of the Modulor adopted a man's height of six foot and was translated it into a decimal measurement system. Le Corbusier claimed that these numbers emerged from Modulor as a proportional measurement tool that are now standards, not just numbers alienated from their sense and human body.

The usual representations of Modulor show a static position of a man standing alone in space, either with a raised hand or leaning against a line of comfortable space equipment. The function of this proportional system was both as a dimensioning tool in space conception but also the present figure in architectural drawing as a de-coder for measurement orientation. Recognized as an inhabitant of Le Corbusier's drawings, the Modulor is obviously a man figure passively spending time in the living space. Taking into account Le Corbusier's concept of promenade architecturale, as one of the most dynamic architectural concepts, the passivity of the Modulor shows that his presence was limited to the technical side of drawing inhabitation; it seems that Le Corbusier had other ways to project himself into his conceived spaces, to unfold complex movement trajectories and manipulate ambiental sensations and space experiences. 
In his research on performances and qualities of lines in architectural drawing, Emmons attributes the flow lines to the imaginative inhabitation of the architectural drawing. These flow lines are traces in the drawing that show the inhabitant's movement through space. As he explains, flow lines were used widely in the twentieth century for studies on living space efficiency. Here he says that "the architect's inhabitative imagination is the ability to put oneself inside a drawing as if occupying the future building rather than looking at the drawing from outside as an object. Architectural design is a projective act of imaginal embodiment. ${ }^{" 30}$ With the ability to project themselves into their drawings, architects are enabling an emphatic relation with future inhabitants and their experiences of the space. Even though scaling is certainly one of the procedures needed for inhabitative imagination in drawing, the expression of this emphatic relation can be presented in various ways - using figures, flow lines or with skilled drawing of space organization.

Evans is researching this subject focusing on figures and space partition in architectural drawings. He says that "if anything is described by an architectural plan, it is the nature of human relationships, since the elements whose trace it records - walls, doors, windows and stairs - are employed first to divide and than selectively to re-unite inhabited space. But what is generally absent in even the most elaborately illustrated building is the way human figures will occupy it." ${ }^{31}$ Evans analyses the presence of the body and its relation to domestic space comparing plan drawings and paintings from the early Renaissance to the ones of twentieth century. He takes the notion of "housing" for an action, instead of a place and aims to read human relationships and the way they inhabit the space. ${ }^{32}$ Focusing on plan drawings, he is also giving an example of flow lines showing a comparative analysis of two spatial organisations: a newly-proposed and the nineteenth-century traditional one. ${ }^{33}$ As Evans explains, the advantage of the new plan was in the fluid circulation of inhabitants though space, where privacy is well protected and any disturbance or fracture of intended movement is reduced to minimum. He is comparing this urge for functional and predetermined efficient movement through space with the complex Renaissance plans and their multiple corridors and overabundant doors. Aiming to criticize architecture's tendency to solve all domestic problems in terms of noise-transition, movement patterns, any disturbance exclusion, he is assuming that this would be an impoverishment of the living space experience: "...there is surely another kind of architecture that would seek to give full play to the things that have been so carefully masked by its anti-type; an architecture arising out of the deep fascination that draws people towards others; an architecture that recognizes passion, carnality and sociality." ${ }^{34}$ 


\section{NEW BABYLON AND FREEDOM OF UN-DOING}

New Babylon could provide an adequate proposition to Evans's "another kind of architecture" and that seeking for "passion, carnality and sociality" can be captured in Constant's drawings. The idea of play was fundamental for Constant, hence living space in New Babylon was dynamic and unpredictable, in permanent change. So even if it was planed on the scale of a planet, the basis of this conception was the smallest scale of living space gestures and their nuances.

Wigley says that Constant was in "every sense a paper architect" and that the concept of his project New Babylon was suitable for drawing media - "the freedom of drawing, the sense of a neutral surface that can accommodate any mark, would seem an ideal way of communicating the freedom of life in New Babylon" - but, his relation to drawing was very specific and even problematic. $^{35}$ He looks for possible reasons exactly in this compelling correspondence between media and project conception, but also in the very nature of the drawing media, which seems to be treated in Constant's work with a distance, like a secondary choice, as if it emerged after the numerous models that he made. Following this analysis it seems that Constant's drawings were in a way unstable, neither sketchy nor presentational, yet complex, numerous and seductive.

According to Wigley, New Babylon is "the largest architectural project in human history, describing a hovering structure that would spread itself around the globe like viral organism until it formed a single building at the size of a planet to host the lives and dreams of everyone." ${ }^{\prime 36} \mathrm{He}$ sees in New Babylon's notion of hospitality a key quality of the project that has been developed and questioned by its author for almost two decades. "The architecture of hospitality therefore appears only in order to be undone or appears only through an undoing. It tries to undo its own authority, removing as many constraints as possible in order to offer the widest and deepest welcome but wants to be undone again and again by the people, actions and ideas that it hosts. The architecture of hospitality is never simple or static: it is a relentless labor of deconstruction." ${ }^{37}$

One fold of hospitality's notion certainly appears through figures or evidence of their presence in Constant's drawings. Human presence is not always exposed, but when figures are shown, they are usually in perspective views. Although they are revealing precisely space proportions, unlike the Modulor, these figures are in movement, braided in their trajectories, behaving like they 
are not aware that they are captured in drawing.(Figure 1)Wigley points out the difference in the figure appearance between Constant's drawings from the sixties and his late drawings from the seventies. Figures in the sixties were shown as a blurry blotches, without any identity specificity, "they bear no markings of age, race, gender - just blurs that communicate difference without revealing what the difference is - a set of mobile question marks. ${ }^{38}$ (Figure 2) In his later drawings towards the end of New Babylon's conception, clues on gender and age are present. Constant used these figures to criticise and question the fundamental ideas of his project. The other side of freedom and hospitality is exposed through scenes of violence and blood traces. Hide Haynen claims in her view on New Babylon that "utopia like this, however, is full of internal contradictions [...] dynamism, permanent change, and flexibility are in fact ineluctably in conflict with qualities such as peace, repose, and harmony." ${ }^{39}$ (Figure 3)

Since the dynamic and continuous questioning of the living space are primarily important for New Babylon, the main task for Constant as an author was to capture this ever changing paysage of architecture and human relations. Wigley points out that his relation to drawing was different within the Situationist International and after his resignation - while his first drawings were aiming to use precise techniques to present play and change in conceived space, his later drawings were experimenting the concept of play and change within the drawing techniques.(Figure 4) Regarding the information which follows his drawings, there is not more than a title - adding descriptive layer like a micromanual for drawing reading, but with no scale data. The viewer is invited for scaling imagination as a part of an observing process with various possible outcomes. This relation to scale as well as drawing titles are something that follows both phases of Constant's drawings. He was clearly using the architectural conventions of a plan, with sections and perspective views, which are sometimes also labelled in a drawing title, but there are no more than ruled ink lines of space structure and mechanisation that approached his work to a technical drawing. He is at the same time using and obstructing architectural drawing practice. With simple materiality and disciplined technique, along with complex materialities and inventive tracing methods, dealing with scale stayed one of the primary issues of New Babylon. It is not a question whether an elastic nexus between drawing materiality, drawing technique and drawing title is giving diverse possibilities for decoding the scale, but whether it points out the scale's relativity. New Babylon's scaling is in a direct causal relation to its activist motivation and the pursue for a societal critique on all levels of society. 


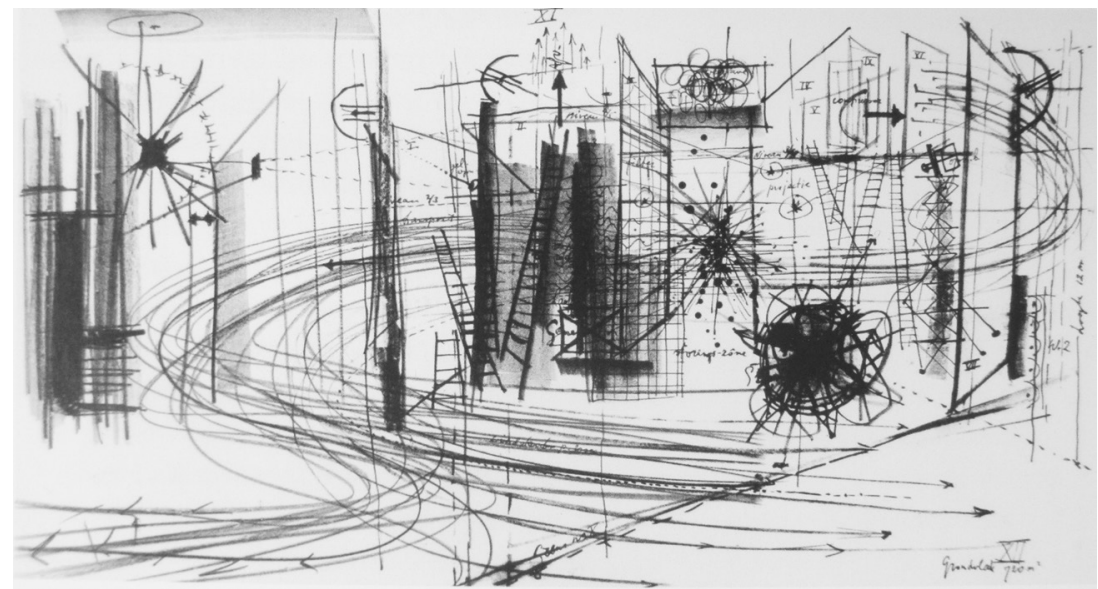

Figure 1. Constant, New Babylon, Lithograph no.9, 1963, 40x38 cm, Gemeentemuseum Den Haag [in: New Babylon: To Us, Liberty, ed. Constant et al. (Ostfildern: Hatje Cantz Verlag, 2016), 42]

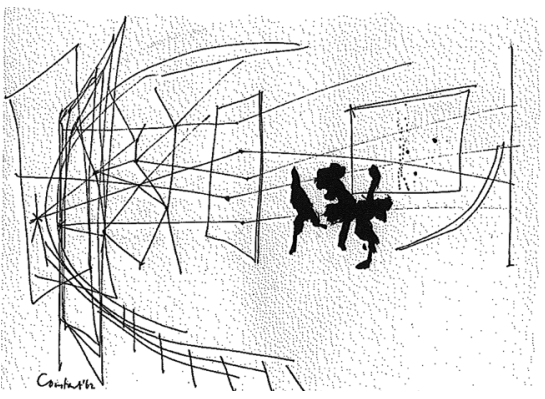

Figure 2. Constant, Figuren in een labyrint, Ink on paper, $1962,39.5 \times 64 \mathrm{~cm}$, Private collection

[in: The Activist Drawing: Retracing Situationist Architectures from Constant's New Babylon to beyond, ed. M. Catherine de Zegher and Mark Wigley (New York: Cambridge, Mass: Drawing Center ; MIT Press, 2001), 65]

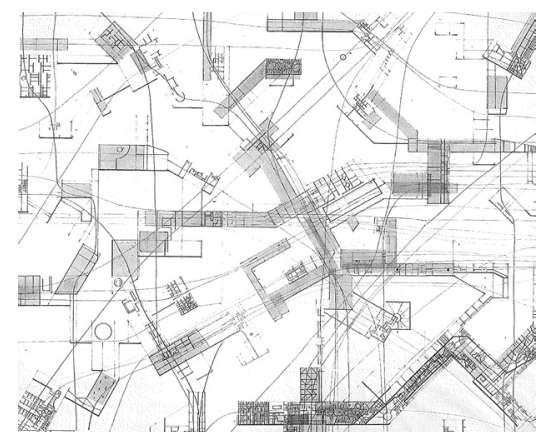

Figure 4. Constant, Groep sectoren,

Collotype, with ink and collage, 1960, 57x68 cm,

Gemeentemuseum Den Haag [in: The Activist

Drawing: Retracing Situationist Architectures from

Constant's New Babylon to beyond, ed. M. Catherine

de Zegher and Mark Wigley (New York: Cambridge,

Mass: Drawing Center; MIT Press, 2001), 33]

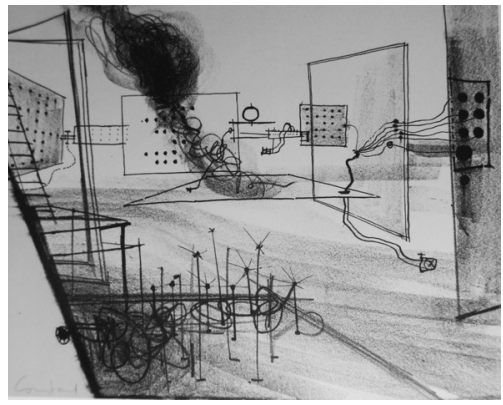

Figure 3 . Constant, Labyrismen, Lithograph no. $12,1968,38 \times 47.5 \mathrm{~cm}$, Gemeentemuseum Den Haag [in: New Babylon: To Us, Liberty, ed. Constant et al. (Ostfildern: Hatje Cantz Verlag, 2016), 48]

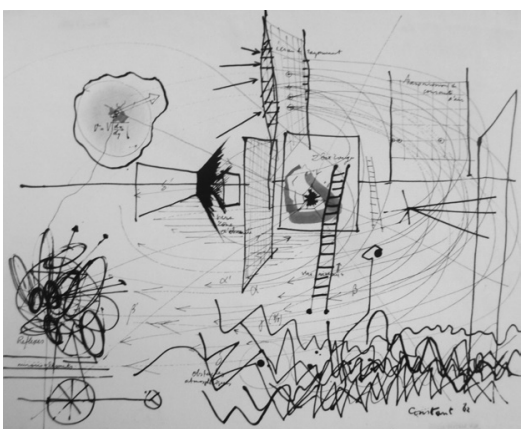

Figure 5 . Constant, Labyratoire, India ink and colored ink on paper, 1962, 48x69 cm,

Gemeentemuseum Den Haag [in: New Babylon: To Us, Liberty, ed. Constant et al. (Ostfildern: Hatje Cantz Verlag, 2016), 43] 


\section{SCALING PER INHABITING}

The matter of inhabiting the drawing is considered here as a dominant nuance in Constant's drawing hypothesis. The specificity in his practice of drawing inhabitation is expressed in the synchronisation of a technical and an imaginative approach where procedure of scaling is not entrusted exclusively to the architect as an author but is expected from the viewer's perspective of a New Babylon inhabitation. The key to this drawing practice is in the intensive relation between drawing methods and the concept of the project, as Wigley claims: "In the very technique of drawing, Constant encounters the logic of the project that he is trying to represent. As the drawings of New Babylon slide from "mechanical" to "expressive", the relentless smoothness of the slide, the extremely minor variations from drawing to drawing, and the repetition of the same images in different media, effectively undermine the standard oppositions. The collapse of distinction between mechanization and spontaneous originality that is meant to be enacted by New Babylon is first enacted on paper." ${ }^{40}$ For Wigley, the ruled lines and grids which Constant was using for the technical and mechanical aspects of the drawings are always distorted by fluid hand lines of movement, flow lines of unexpected events and human figures.(Figure 5)

The inhabitants of New Babylon are invited to use their creativity and playfulness instead of work and contribution to the social and political order. They are meant to be free from any social responsibilities and expected to freely change their living space on everyday level, thus contributing to the everchanging city environment. Getting lost while on a neighbourhood promenade is the desired situation. This lifestyle projected in Constant's drawings is blurry, precisely defined but elusive. Using drawing materiality, various techniques and different levels of information, he is explicitly communicating the leading space concepts but not the exact space appearance: "The point was to never reveal what New Babylon looks like yet to provoke desire for it. ${ }^{\prime 41}$ The only way of insight in this hospitality is through active observation and personal envision of the idea in the observer-inhabitant's creative mind. "Constant simply designs the three-dimensional paper on which people will draw their lives." ${ }^{\prime 2}$ With Constant's hypothesis, conceptual ideas and space qualities were ably conceived and communicated to the spectator who in turn became an active free node in the relational chain architect-(inhabitant)project-(inhabitant)-object-(inhabitant). In this way, the basic instabilities of drawing media are turned in the eye of the observer in order to elicit scaling judgements through inhabitation. 
Mark Wigley, "Paper, Scissors, Blur," in The Activist Drawing: Retracing Situationist Architectures from Constant's New Babylon to beyond, ed. M. Catherine de Zegher and Mark Wigley (New York : Cambridge, Mass: Drawing Center ; MIT Press, 2001), 29.

David R. Scheer, The Death of Drawing: Architecture in the Age of Simulation (London ; New York: Routledge, 2014), 3.

Robin Evans, "Translations from Drawing to Building," in Translations from Drawing to Building and Other Essays, ed. Robin Evans, AA Documents 2 (London: Architectural Association, 1997), 154.

Ibid., 155.

Ibid.

Marco Frascari, "A Reflection on Paper and Its Virtues within the Material and Invisible Factures of Architecture," in From Models to Drawings: Imagination and Representation in Architecture, ed. Marco Frascari, Jonathan Hale, and Bradley Starkey (London ; New York: Routledge, 2007), 23.

7 Ibid.

8 Ibid., 26.

$9 \quad$ Ibid., 27.


Ibid., 26.

Wigley, "Paper, Scissors, Blur," 29.

Bert Bielefeld and Isabella Skiba, Technical Drawing (Basel: Birkhäuser, 2013), 18.

Ibid.

Ibid., 7.

Paul Emmons, "Drawn to Scale. The Imaginative Inhabitation of Architectural Drawings," in From Models to Drawings: Imagination and Representation in Architecture, ed. Marco Frascari and Jonathan Hale (London ; New York: Routledge, 2007), 64. Ibid., 65.

Ibid., 66.

Evans, "Translations from Drawing to Building," 160.

Ibid., 154.

Emmons, "Drawn to Scale. The Imaginative Inhabitation of Architectural Drawings," 71.

Ibid.

Bert Bielefeld and Isabella Skiba, Technical Drawing, 18.

Emmons, "Drawn to Scale. The Imaginative Inhabitation of Architectural Drawings," 71.

Nicolas Malebranche, The Search after Truth, ed. Thomas M. Lennon and Paul J. Olscamp, Cambridge Texts in the History of Philosophy (Cambridge ; New York: Cambridge University Press, 1997), 429.

David R. Scheer, The Death of Drawing: Architecture in the Age of Simulation, 69.

Emmons, "Drawn to Scale. The Imaginative Inhabitation of Architectural Drawings," 68.

In a previous research, Anđelka Bnin-Bninski used scaling procedure for drawing experiments on properties of the line and also as a theoretical research method for analysing the dynamics of living space partition. From a methodological perspective, her research showed that scale as a "perception technique" can be used for synchronized discussion on a drawing and on theoretical level. For more information, see https://fvm.academia.edu/AnđelkaĆirovićBninBninski Ibid., 72.

Le Corbusier, The Modular: A Harmonius Measure to the Human Scale Universally Applicable to Architecture and Mechanics (New York: Faber, 1961), 46.

Paul Emmons, "Demiurgic Lines: Line-Making and the Architectural Imagination," The Journal of Architecture 19, no. 4 (July 4, 2014): 550, doi:10.1080/13602365.2014.949822. Essays, ed. Robin Evans, AA Documents 2 (London: Architectural Association, 1997), 56. Ibid., 80.

Evans is referring to a 1928 study titled "The Functional House for Frictionless Living" by Alexander Klein who builds an argument comparing the flow lines of a newly-proposed house plan with typical nineteenth-century floor plan. (Ostfildern: Hatje Cantz Verlag, 2016), 39.

Ibid.

Ibid., 43.

Hilde Heynen, Architecture and Modernity: A Critique (Cambridge, Mass: MIT Press, 1999), 173. Wigley, "Paper, Scissors, Blur," 42.

Ibid., 52.

Ibid. 
Bielefeld, Bert, and Isabella Skiba. Technical Drawing. Basics. Basel: Birkhäuser, 2013.

Constant, Benno Tempel, Rem Koolhaas, Pascal Gielen, Trudy Nieuwenhuis, Laura Stamps, Willemijn Stokvis, Mark Wigley, Hatje-Cantz-Verlag, and Haags Gemeentemuseum, eds. New Babylon: To Us, Liberty. Ostfildern: Hatje Cantz Verlag, 2016.

Constant, M. Catherine de Zegher, Mark Wigley, and Drawing Center (New York, N.Y.), eds. The Activist Drawing: Retracing Situationist Architectures from Constant's New Babylon to beyond. New York : Cambridge, Mass: Drawing Center ; MIT Press, 2001.

Emmons, Paul. 'Demiurgic Lines: Line-Making and the Architectural Imagination'. The Journal of Architecture 19, no. 4 (4 July 2014): 536-59. doi:10.1080/13602365.2014.949822.

—. 'Drawn to Scale. The Imaginative Inhabitation of Architectural Drawings'. In From Models to Drawings: Imagination and Representation in Architecture, edited by Marco Frascari and Jonathan Hale, 64-78. London ; New York: Routledge, 2007.

Evans, Robin. 'Figures, Doors, Passages'. In Translations from Drawing to Building and Other Essays, edited by Robin Evans, 55-90. London: Architectural Association, 1997.

_. 'Translations from Drawing to Building'. In Translations from Drawing to Building and Other Essays, edited by Robin Evans, 153-93. London: Architectural Association, 1997.

Frascari, Marco. 'A Reflection on Paper and Its Virtues within the Material and Invisible Factures of Architecture'. In From Models to Drawings: Imagination and Representation in Architecture, edited by Marco Frascari, Jonathan Hale, and Bradley Starkey, 23-34. London; New York: Routledge, 2007.

Heynen, Hilde. Architecture and Modernity: A Critique. Cambridge, Mass: MIT Press, 1999.

Le Corbusier. The Modular: A Harmonius Measure to the Human Scale Universally Applicable to Architecture and Mechanics. New York: Faber, 1961.

Malebranche, Nicolas. The Search after Truth. Edited by Thomas M. Lennon and Paul J. Olscamp. Cambridge Texts in the History of Philosophy. Cambridge ; New York: Cambridge University Press, 1997.

Scheer, David R. The Death of Drawing: Architecture in the Age of Simulation. London; New York: Routledge, 2014.

Wigley, Mark. 'Extreme Hospitality'. In New Babylon: To Us, Liberty, edited by Constant, Benno Tempel, Rem Koolhaas, Pascal Gielen, Trudy Nieuwenhuis, Laura Stamps, Willemijn Stokvis, Mark Wigley, Hatje-Cantz-Verlag, and Haags Gemeentemuseum, 38-49. Ostfildern: Hatje Cantz Verlag, 2016.

Wigley, Mark. 'Paper, Scissors, Blur'. In The Activist Drawing: Retracing Situationist Architectures from Constant's New Babylon to beyond, edited by M. Catherine de Zegher and Mark Wigley, 27-68. New York : Cambridge, Mass: Drawing Center ; MIT Press, 2001. 


\section{RAZMERA NA PAPIRU IZMEDJU TEHNIKE I IMAGINACIJE. PRIMER KONSTANTOVE CRTAČKE PRETPOSTAVKE \\ Anđelka Bnin-Bninski, Maja Dragišić}

Postupak razmeravanja je jedna od osnovnih radnji u arhitektonskom crtanju. Uz papir kao kao osnovni materijal za crtanje, razmera predstavlja arhitektonsku konvencija odmah po samom crtanju u arhitekturi Renesanse. U ovom radu ispituje se procedura razmeravanja iz pozicije crteža u idejno-stvaralačkom arhitektonskom procesu. Aktuelna teorijska istraživanja o arhitektonskom crtežu ističu promenu paradigme koja se dogodila usled iznenadnog prelaska sa ručnog na kompjuterski crtež. Ova promena je posledično uticala na materijalni značaj crtanja/crteža, odnosa prema razmeri i geometriji. Argumentujući razmeru kao dvoznačnu radnju, tehničku i kreativnu, Konstantovi crteži Novog Vavilona uzeti su kao primer problematizacije relacionog lanca arhitekta - projekat - objekat.

KLJUČNE REČI: ARHITEKTONSKI CRTEŽ, RAZMERA, PAPIR, CRTEŽ STANOVANJA, KONSTANTOV NOVI VAVILON

\section{IZVAN PROPORCIJA \\ Reinterpretacija proporcija - između konceptualnog $i$ \\ perceptivnog mišijenja arhitekture \\ (komunikativna dimenzija grada)}

\section{Miloš Mihajlović, Aleksandra Subotić, Vladimir Parežanin}

Rad posmatra proporcuju kao alat kojim se urbanista i arhitekta koriste da bi se postigao određeni kvalitet prostora. Kako se kroz proporciju posmatraju odnosi celine i njenih delova, tako rad sagledava aspekte prostora od prostornog plana grada do arhitektonskog detalja. Takođe, i pored toga što je proporcija odnos dimenzija fizičkih elemenata u prostoru, rad razmatra proporciju i kroz odnos materijalnih i nematerijalnih aspekata prostora. Na taj način, težište rada je pomereno na nivo komunikacije između arhitektonsko-urbanističkog prostora i njegovih korisnika, odnosno na orkestraciju kroz percepciju i doživljaj prostora, a ne na prevaziđenu, proporcijsku analizu arhitektonske forme.

KLJUČNE REČI: ARHITEKTONSKO PROJEKTOVANJE, ISTRAŽIVANJE KROZ DIZAJN, ODNOS, PROPORCIJE, ESTETIKA, MODULOR, REZILIJENTNOST

\section{MODELI TRANSFORMACIJE NEISKORIŠČENIH PROSTORNIH RESURSA Istraživačka studija KC Magacin u Beogradu \\ Ksenija Pantović, Iva Čukić}

Ovaj rad istražuje različite modele transformacije neiskorišćenih prostornih resursa, u cilju prepoznavanja aspekata koji vode održivom aktiviranju prostora. Značaj istraživanja ogleda se i u naučnoj interpretaciji i pojašnjenju fenomena transformacije $u$ aktiviranju neiskorišćenih prostornih resursa, i to u kontekstu post-socijalističke Srbije sa posebnim fokusom na glavni grad. Istovremeno, ovaj rad predstavlja i doprinos metodologiji arhitektonskog projektovanja, kroz ukazivanje na značaj primene modela transformacije u projektantskom procesu. U tom kontekstu, teorijski okvir istraživanja se odnosi na različite aspekte urbane održivosti u kontekstu aktiviranja neiskorišćenih prostornih resursa, kao i na dublje razjašnjavanje uloge principa transformacije u arhitektonskom diskursu. Empirijski deo istraživanja se odnosi na analizu studije slučaja konkretnog prostornog okvira Kulturnog centra Magacin u Beogradu i to metodom sprovođenja studentske radionice. Studenti istražuju različite mogućnosti transformacije i aktivacije prostora, kroz niz predloženih intervencija. Završni deo rada obuhvata sintezu i interpretaciju rezultata u odnosu na kontekst istraživanja i postavljene problemske postavke, ali što je značajnije, daje stepen uslovljenosti 